\title{
Effects of Macleaya cordata extract supplementation in milk on growth performance, some biochemical parameters and a number of selected bacterial groups of the recto-anal microbiota of calves
}

\author{
NESE NURAY TOPRAK
}

Department of Animal Science, Faculty of Agriculture, University of Ankara, 06110, Ankara, Turkey

\section{Toprak N. N.}

Effects of Macleaya cordata extract supplementation in milk on growth performance, some biochemical parameters and a number of selected bacterial groups of the recto-anal microbiota of calves

\section{Summary}

The objective of this study was to investigate the effects of milk Macleaya cordata extract supplementation on the weight gain, feed intake, serum total protein (TP), albumin, globulin, IgG, blood urea nitrogen (BUN), triglyceride (TG), beta-hydroxy butyric acid (BHBA) levels, alkaline phosphatase (ALP), aspartate aminotransferase (AST), alanine aminotransferase (ALT) levels and total aerobic, lactobacillus and coliform bacterial counts of recto-anal swabs in Simmental calves. The feeding study was carried out using $20(\mathrm{n}=10)$ 4-day-old Simmental calves (average birth weight $45.55 \pm 1.53 \mathrm{~kg}$ ) from December 2017 to May, 2018. The experimental treatments comprised milk without any additive (control) and milk with $1 \mathrm{~g} \mathrm{M}$. cordata extract added per head per day. The calves were fed with only colostrum until 4 days of age and then with 5 liters per day of whole milk until the end of 65 days. At the end of the study, a significant difference in body weights and feed efficiency between the groups was not observed. During the $4^{\text {th }}-6^{\text {th }}$ weeks of the trial, $M$. cordata extract supplementation in milk decreased the feed intake of the calves. The serum TP, albumin, IgG, BHBA, TG, BUN, ALP and ALT levels were also found to be not statistically different between the treatment groups. At the end of the experiment the serum albumin and BHBA levels were increased, whereas the BUN levels were decreased. There was a significant effect of the group $\times$ sex interaction on the serum AST levels. The total aerobic, total coliforms, and lactobacillus bacterial counts of the recto-anal swabs were not different between the experimental groups. In conclusion, the present data demonstrated that supplementation of pre-weaning calves' milk with $M$. cordata at $1 \mathrm{~g}$ per day did not improve growth performance but changed their metabolic status.

Keywords: blood parameters, calf, IgG, growth, Macleaya cordata

Breeding calves is a crucial and sensitive management issue in dairy farms. The control of calves' metabolic status, milk feeding and feed consumption is equally important for the health and productivity of dairy herds. For this reason, it is very important to apply proper methods of nutrition in order to enhance the growth, immunity, and health of dairy calves (2). At birth, a calf is considered to be a functional monogastric because its rumen is undeveloped and incapacitated; especially papillary growth, rumen wall absorption surface and muscularization are very limited. The period of transition from a pre-ruminant to a ruminant is critical and vital and can be influenced by feeding management. Hence, the suckling period for young ruminants represents the time of life when dairy animals are most at risk of a number of health problems and even death. Calf morbidity and mortality are important indicators of the health status of a herd (29). The rate of calf mortality varies considerably among farms, depending on calf rearing standards in particular countries. Several authors report calf loss rates in different countries: in Turkey in 2017, the calf mortality rate was high at $15 \%$.

The mortality rate for live born dairy calves up to 1 year of age amounted to $10.7 \%$ in Korea (13), 6.9$-7.8 \%$ in the United States (42), and $4.6 \%$ in Norway (10). A survey reported a mortality rate of $14.5 \%$ from birth to first calving in the United Kingdom (5) and 
an average of $2.0-6.0 \%$ for calves up to 6 months of age in British cattle farms (29). Diarrhea is the main cause of morbidity and mortality in the early lives of calves and can cause substantial economic losses due to growth depression and the need for medication (31). The National Animal Health Monitoring System reported that $57.0 \%$ of calf mortality was due to diarrhea and most cases occurred in the first 3-4 weeks of a calf's life (39). In addition, scours, pneumonia, other infectious diseases, navel infections, stress, and immunity problems all contribute to the mortality and morbidity of calves. Economic losses are due not only to mortality, but also to the costs of treatment, veterinary intervention, diagnostics, and labor, and to the decreased rate of herd replacement as well as to impaired growth performance (4). Calfhood diseases and calf deaths have a major impact on the economic viability of cattle operations and can lead to substantial economic loss and animal welfare concerns (8).

Plant extracts or phytogenic feed additives (phytobiotics) are used in animal nutrition. Phytogenic feed additives can be added to feed as dried whole or partial plant extracts like antioxidants, digestion stimulants, flavour and appetite enhancers, preventative and curative treatments for certain pathological conditions, and so on. These extracts are a wide range of plant-derived products such as essential oils, alkaloids, spices, and herbs. Phytobiotics have been studied as prophylactics in intensive systems to maintain intestinal balance, to improve performance and immunity, as well as to reduce the incidence of intestinal pathogens. Phytobiotics act along the animal's digestive tract to improve appetite and bacterial modulation, and can have a very positive effect on the animal's well-being (15). Phytogenic feed additives may assist in improving digestive processes, particularly during the early stages of life, ultimately resulting in improved performance and health $(9,35,43)$. Macleaya cordata (M. cordata) has been recognized as a traditional herb that is distributed primarily in China, North America and Europe, and has a long history of use in therapeutic practice (32). Currently, extracts from these medicinal plants are components of veterinary and human phytopreparations (40). M. cordata is recognized by the European Food Safety Authority (EFSA) as a feed additive for animal production. Recently, studies have focused on Macleaya due to their biological effects, such as anti-inflammatory, antimicrobial, insecticidal, and antitumor effects $(19,21,32)$. Liu et al. (25) reported that $M$. cordata extract may improve the intestinal barrier function in growing piglets and that it might be used as an antibiotic. M. cordata contains several alkaloids, such as berberine, bocconine, chelerythrine (active ingredient), ethoxysanguinarine, oxysanguinarine, protopine, and sanguinarine (active ingredient) (7). Extracts from these plants containing quaternary benzo[c]phenanthridine alkaloids (QBAs) have also been used as antifungal and antimicrobial agents in human medicines (23) and have been shown to have anti-inflammatory $(23,37)$ and immunomodulatory effects (6).

Our knowledge about the modes of action of phytogenic feed additives and their effects on suckling calf metabolism is still rather limited. This experiment was designed to provide experimental data on the effects of feeding $M$. cordata extract to pre-weaning dairy calves. The aim of this experiment was to investigate the effect of $M$. cordata extract on the growth, dry matter intake, feed efficiency, serum total protein (TP), albumin, globulin, IgG, blood urea nitrogen (BUN), triglyceride (TG), beta-hydroxy butyric acid (BHBA), alkaline phosphatase (ALP), aspartate aminotransferase (AST), alanine aminotransferase (ALT) levels and recto-anal total aerobic, coliforms and lactobacillus bacterial counts of pre-weaning Simmental calves.

\section{Material and methods}

The experimental animals were kept, maintained, and treated in adherence to accepted standard ethical norms. The research was carried out using a total of 20 Simmental calves during the period from December 2017 to May 2018. The trial was conducted on a dairy cattle farm in Ankara province (coordinates: $39^{\circ} 52^{\prime} 52.6188^{\prime \prime} \mathrm{N}$ and $\left.33^{\circ} 16^{\prime} 50.3868^{\prime \prime} \mathrm{E}\right)$. Calves were allotted to the experimental groups based on their birth weight and sex. The health status of the calves was monitored daily. The calves were housed in straw-bedded individual pens $(1.2 \times 1.8 \mathrm{~m})$. The calves were weighed at birth, at one month of age and at the end of the trial ( $2^{\text {nd }}$ month, day 65$)$. During the study, all occurrences and treatments of disease and injury were noted individually. At the end of the trial, all the calves were gradually weaned.

The experimental treatments used in the study were (1) control milk without any additive $(\mathrm{n}=10)$ and $(2)$ milk with $1 \mathrm{~g}(0.5 \mathrm{~g}$ per morning feeding and $0.5 \mathrm{~g}$ per evening feeding) $(\mathrm{n}=10)$ Alkamax $^{\circledR}$ (resulted in $290 \mathrm{mg} / \mathrm{d}$ M. cordata extract) per head per day. M. cordata extract (water soluble) is a supplementary feed that consists of acids and special active components from Papaveraceae extracts, such as QBAs and Protopine alkaloids. The calves were fed with colostrum only until they reached 4 days of age and then with whole milk at the 5 liter/day until the end of 65 days. During the entire trial, each calf was fed colostrum twice a day, and the $M$. cordata extract supplement in the whole milk for the calves was administered daily from experimental day 4 to 65 . Milk was fed to the calves at $38-39^{\circ} \mathrm{C}$ twice a day, at 08:30 am and 06:00 pm, by bottle. The calves also had free access to calf starter feed (from the $2^{\text {nd }}$ week) and alfalfa hay (from the $4^{\text {th }}$ week), which were offered to the calves in a separate bucket. Individual concentrated feed and hay intake were measured every week by measuring the difference between the feed offered and the feed refused. Dry matter, crude protein, crude fiber, crude ash and crude fat in the calf starter and the alfalfa hay were analyzed according to the methods in AOAC (3). The dry matter, protein and fat content of the milk were measured using the infrared method and the Combifoss 5400 (Foss Electric, Hillerod, 
Tab. 1. The analyzed and calculated nutrient content in the diet fed to the pre-weaning calves

\begin{tabular}{|l|c|c|c|}
\hline \multicolumn{1}{|c|}{ Nutrients } & Whole milk & Calf starter & Alfalfa hay \\
\hline DM, \% & 12.81 & 87.88 & 86.37 \\
Ash,\% & - & 8.50 & 9.99 \\
CF,\% & - & 7.79 & 23.30 \\
CP,\% & 3.44 & 17.83 & 15.92 \\
EE,\% & 4.00 & 4.10 & 1.61 \\
ME, kcal kg- $^{-1}$ & - & 2532.80 & 1875.00 \\
\hline
\end{tabular}

Explanations: DM - dry matter; $\mathrm{CF}$ - crude fiber; $\mathrm{CP}$ - crude protein; EE - ether extract; ME - metabolisable energy

Denmark). The chemical composition of the starter feed, alfalfa hay, and milk are shown in Tab. 1.

Body weight was measured and recorded at birth for each calf and measured again in the $1^{\text {st }}$ and $2^{\text {nd }}$ months of the experiment by weighing calves in the morning, just after feeding. Blood samples were collected from the jugular vein into vacutainer tubes (BD VACUTAINER ${ }^{\circledR}$ SST, Becton Dickinson Diagnostics, Franklin Lakes, NJ), without anticoagulant, on day 3 and on day 56 (3 hours after the morning feeding) to measure the serum concentrations of total protein, albumin, BUN, TG, BHBA, ALP, AST, ALT levels for each calf. The collected blood was immediately transported to the laboratory and centrifuged at $3500 \mathrm{rpm}$ for 15 minutes at $4^{\circ} \mathrm{C}$, and the serum was frozen at $-20^{\circ} \mathrm{C}$ to await analysis. The total protein, albumin, BUN, TG, BHBA, ALP, AST and ALT levels were measured in the serum using standard procedures and commercial diagnostic kits produced by an automated biochemical analyzer
(Randox Daytona Plus). The serum IgG concentrations (mg/dL) were also determined using Randox Laboratories kits (RX series, United Kingdom). In the final week of the study, recto-anal swabs were collected from each animal using double-tipped, sterile culture swab tubes, and the samples were transported in an ice box to the laboratory within 2 hours then measured to determine their bacterial count. Recto-anal samples were assessed for populations of Lactobacillus, total coliforms and total aerobic bacteria. The populations studied were: total aerobic bacteria (on Plate Count Agar) and, coliform bacteria (on Mac Conkey Agar), both later incubated for 24 hours at $37^{\circ} \mathrm{C}$, and lactic acid bacteria (on Edward Agar), incubated for 48 hours at $37^{\circ} \mathrm{C}$ in microaerophilic conditions.

All data were analyzed using Minitab 16 software. The serum results were analyzed as a randomized complete block with repeated measurements. Before managing statistical analysis of the Lactobacillus, total coliforms and total aerobic bacteria counts, the mean values were transformed by Box-Cox transformations. Duncan's Multiple Range Test was used to compare the differences between the treatment groups. The gender of the calves was considered as a factor in the statistical model. All values with $\mathrm{P} \leq 0.05$ were regarded as statistically significant.

\section{Results and discussion}

During the study, no mortality or morbidity was observed in any group, and the general health status of calves was normal. The mean values of the body weights and body weight gains of the calves are shown for each period in Table 2. As shown in Table 2, the

Tab. 2. Effects of Macleaya cordata extract supplementation to milk on body weight gain, feed intake and FE of pre-weaning calves

\begin{tabular}{|c|c|c|c|c|c|c|c|}
\hline \multirow{2}{*}{ Parameters } & \multicolumn{2}{|c|}{ Groups } & \multicolumn{2}{|c|}{ Sex } & \multicolumn{3}{|c|}{$P$ values } \\
\hline & Control & M. cordata & 우 & $0^{\pi}$ & G & S & $G \times S$ \\
\hline Birth weight (kg) & $45.55 \pm 2.080$ & $45.56 \pm 0.970$ & $42.82 \pm 1.400$ & $46.73 \pm 1.390$ & 0.855 & 0.130 & 0.656 \\
\hline \multicolumn{8}{|l|}{ BW (kg) } \\
\hline day 30 & $60.06 \pm 1.750$ & $60.44 \pm 1.250$ & $58.93 \pm 1.930$ & $60.81 \pm 1.260$ & 0.940 & 0.448 & 0.567 \\
\hline day 65 & $90.58 \pm 2.780$ & $92.49 \pm 1.560$ & $88.83 \pm 2.760$ & $92.69 \pm 1.880$ & 0.679 & 0.294 & 0.776 \\
\hline \multicolumn{8}{|l|}{ DBWG (kg) } \\
\hline day 1 to 30 & $0.45 \pm 0.052$ & $0.46 \pm 0.021$ & $0.50 \pm 0.071$ & $0.44 \pm 0.026$ & 0.725 & 0.297 & 0.169 \\
\hline day 30 to 65 & $0.90 \pm 0.039$ & $0.94 \pm 0.023$ & $0.87 \pm 0.040$ & $0.94 \pm 0.026$ & 0.323 & 0.200 & 0.661 \\
\hline day 1 to 65 & $0.67 \pm 0.028$ & $0.70 \pm 0.011$ & $0.69 \pm 0.038$ & $0.69 \pm 0.015$ & 0.653 & 0.982 & 0.361 \\
\hline Total BWG $(\mathrm{kg}) \mathrm{d} 1$ to 65 & $45.03 \pm 1.870$ & $46.93 \pm 0.763$ & $46.02 \pm 2.540$ & $45.96 \pm 1.030$ & 0.653 & 0.982 & 0.361 \\
\hline \multicolumn{8}{|l|}{ FI (g/day) } \\
\hline week 2 to 4 & $375.7 \pm 65.80$ & $232.8 \pm 35.40$ & $307.3 \pm 49.00$ & $381.0 \pm 54.50$ & 0.534 & 0.405 & 0.745 \\
\hline week 4 to 6 & $607.1 \pm 15.10^{a}$ & $525.5 \pm 37.10^{b}$ & $559.5 \pm 36.50$ & $575.4 \pm 27.60$ & 0.040 & 0.734 & 0.214 \\
\hline week 6 to 8 & $797.2 \pm 24.20$ & $768.2 \pm 27.20$ & $798.5 \pm 23.90$ & $773.7 \pm 25.80$ & 0.406 & 0.526 & 0.660 \\
\hline week 2 to 8 & $593.3 \pm 32.30$ & $539.2 \pm 26.00$ & $555.1 \pm 33.20$ & $576.7 \pm 29.60$ & 0.218 & 0.668 & 0.491 \\
\hline Alfalfa hay intake & $258.0 \pm 12.50$ & $249.3 \pm 11.90$ & $252.1 \pm 13.00$ & $255.1 \pm 11.80$ & 0.699 & 0.904 & 0.816 \\
\hline Total DMI & $1394.8 \pm 38.80$ & $1339.3 \pm 29.90$ & $1355.8 \pm 36.70$ & $1377.6 \pm 35.60$ & 0.303 & 0.724 & 0.665 \\
\hline $\mathrm{FE}$ & $2.11 \pm 0.094$ & $1.89 \pm 0.031$ & $2.00 \pm 0.104$ & $2.02 \pm 0.073$ & 0.101 & 0.941 & 0.489 \\
\hline
\end{tabular}

Explanations: BW - body weight; BWG - body weight gain; DBWG - daily body weight gain; FI - starter feed intake; DMI - dry matter intake; FE - feed efficiency = expressed as ratio of kilogram of DM to kilogram of gain; $\mathrm{G}-$ group; $\mathrm{S}-\mathrm{sex}$; $\mathrm{a}, \mathrm{b}-\mathrm{means}$ within a row without common superscripts are different at $\mathrm{P}<0.05$. 
results were not statistically significant between the groups. Similar body weight gain results were obtained by Zhao et al. (46). Zhao et al. (46) reported that the addition of $0,3.5,17.5,35.0 \mathrm{mg}$ of $M$. cordata extract per kilogram of feed for ninety days did not improve the bodyweight gain in piglets fed corn-soybean meal-based basal diets. Moser et al. (28), Kozlowski et al. (20), and Zdunczyk et al. (45) also observed no significant differences with respect to the average daily body weight gain of broilers in the control group and in the experimental group that received Sangrovit, derived from $M$. cordata. On the other hand, the results of studies by Lindermayer (24) indicated beneficial effects and a 2-4\% live weight gain achieved by using Sangrovit in swine diets. Similarly, a study on 3 to 23 day old dairy calves suggested that supplementing $5 \mathrm{~g} /$ meal of QBA+PA into the milk replacer had a positive effect on body weight gain ( $\mathrm{P}=0.070)(34)$.

The results of this study also showed no statistically significant differences in the feed intake, total dry matter intake, and feed efficiency (FE) between the $M$. cordata extract supplemented groups and the control groups (Tab. 2). However, while M. cordata extract supplementation had no effect on the total dry matter intake during the experimental period, M. cordata extract reduced the average feed intake of the experimental group during weeks 4-6 as compared to the control group $(\mathrm{P}<0.050)$. Similarly, in an experiment on chicken fed a corn-soybean meal based basal diet supplemented with $0,3.7,18.5$, and $37.0 \mathrm{mg}$ of $M$. cordata extract per kilogram of feed, no statistically significant differences in FCR were noted between the

Tab. 3. Effects of Macleaya cordata extract supplementation to milk on blood biochemical parameters of pre-weaning calves

\begin{tabular}{|c|c|c|c|c|c|c|c|}
\hline \multirow{2}{*}{ Parameters } & \multirow{2}{*}{ Time } & \multicolumn{2}{|c|}{ Groups } & \multicolumn{2}{|c|}{ Sex } & \multicolumn{2}{|c|}{ P-value of interactions } \\
\hline & & Control & M. cordata & q & $\hat{o}$ & $G \times S$ & $T \times G \times S$ \\
\hline \multirow[t]{2}{*}{$\mathrm{TP}(\mathrm{g} / \mathrm{dL})$} & Day 3 & $6.22 \pm 0.600$ & $5.87 \pm 0.503$ & $5.46 \pm 0.540$ & $6.31 \pm 0.490$ & \multirow{2}{*}{0.859} & \multirow{2}{*}{0.112} \\
\hline & Day 60 & $6.08 \pm 0.410$ & $5.90 \pm 0.210$ & $6.11 \pm 0.393$ & $5.93 \pm 0.283$ & & \\
\hline P-value & 0.593 & \multicolumn{2}{|c|}{0.904} & \multicolumn{2}{|c|}{0.450} & & \\
\hline \multirow[t]{2}{*}{ Albumin ( $g / d L)$} & Day 3 & $2.53 \pm 0.071$ & $2.49 \pm 0.088$ & $2.52 \pm 0.092$ & $2.51 \pm 0.071$ & \multirow{2}{*}{0.544} & \multirow{2}{*}{0.510} \\
\hline & Day 60 & $3.12 \pm 0.192$ & $3.18 \pm 0.165$ & $3.18 \pm 0.148$ & $3.13 \pm 0.169$ & & \\
\hline P-value & 0.002 & \multicolumn{2}{|c|}{0.850} & \multicolumn{2}{|c|}{0.814} & & \\
\hline \multirow[t]{2}{*}{ Globulin (g/dL) } & Day 3 & $3.69 \pm 0.615$ & $3.38 \pm 0.503$ & $2.94 \pm 0.504$ & $3.80 \pm 0.506$ & \multirow{2}{*}{0.237} & \multirow{2}{*}{0.129} \\
\hline & Day 60 & $2.96 \pm 0.257$ & $2.72 \pm 0.161$ & $0.93 \pm 0.280$ & $2.80 \pm 0.184$ & & \\
\hline P-value & 0.441 & \multicolumn{2}{|c|}{0.954} & \multicolumn{2}{|c|}{0.377} & & \\
\hline \multirow[t]{2}{*}{$\lg G(m g / d L)$} & Day 3 & $563.13 \pm 1.67$ & $559.5 \pm 1.75$ & $560.4 \pm 3.23$ & $561.7 \pm 1.23$ & \multirow{2}{*}{0.278} & \multirow{2}{*}{0.789} \\
\hline & Day 60 & $561.75 \pm 2.02$ & $562.0 \pm 0.91$ & $562.4 \pm 1.63$ & $561.6 \pm 1.42$ & & \\
\hline P-value & 0.632 & \multicolumn{2}{|c|}{0.187} & \multicolumn{2}{|c|}{0.770} & & \\
\hline \multirow[t]{2}{*}{ BUN (mg/dL) } & Day 3 & $41.40 \pm 2.760$ & $44.54 \pm 3.440$ & $38.84 \pm 1.460$ & $44.85 \pm 2.960$ & \multirow{2}{*}{0.960} & \multirow{2}{*}{0.437} \\
\hline & Day 60 & $27.50 \pm 2.470$ & $26.94 \pm 0.876$ & $27.40 \pm 2.120$ & $27.14 \pm 1.640$ & & \\
\hline P-value & 0.000 & \multicolumn{2}{|c|}{0.549} & & & & \\
\hline $\mathrm{TG}(\mathrm{mg} / \mathrm{dL})$ & Day 3 & $55.23 \pm 5.510$ & $53.09 \pm 3.770$ & $55.02 \pm 5.730$ & $53.77 \pm 4.100$ & 0100 & 0121 \\
\hline & Day 60 & $53.43 \pm 6.710$ & $44.30 \pm 2.340$ & $46.97 \pm 2.680$ & $49.73 \pm 5.210$ & 0.102 & 0.104 \\
\hline P-value & 0.351 & & & & & & \\
\hline BHBA (mmol/L) & Day 3 & $0.07 \pm 0.005$ & $0.06 \pm 0.007$ & $0.08 \pm 0.008$ & $0.06 \pm 0.005$ & & \\
\hline & Day 60 & $0.28 \pm 0.043$ & $0.29 \pm 0.029$ & $0.28 \pm 0.033$ & $0.29 \pm 0.034$ & 0.090 & 0.002 \\
\hline P-value & 0.000 & & & & & & \\
\hline ALP (IU/L) & Day 3 & $243.1 \pm 69.50$ & $254.3 \pm 39.70$ & $248.2 \pm 30.00$ & $221.6 \pm 56.70$ & 0286 & 0500 \\
\hline & Day 60 & $196.8 \pm 26.50$ & $221.0 \pm 16.70$ & $217.6 \pm 23.40$ & $204.9 \pm 20.40$ & $0 . \angle 00$ & 0.500 \\
\hline P-value & 0.103 & & & & & & \\
\hline AST (IU/L) & Day 3 & $39.82 \pm 2.390$ & $45.93 \pm 7.520$ & $40.29 \pm 4.630$ & $44.05 \pm 5.360$ & 0015 & 0781 \\
\hline & Day 60 & $52.80 \pm 4.300$ & $49.55 \pm 2.990$ & $52.90 \pm 5.970$ & $50.39 \pm 2.770$ & 0.010 & 0.101 \\
\hline P-value & 0.075 & & & & & & \\
\hline ALT (IU/L) & Day 3 & $15.01 \pm 2.160$ & $21.54 \pm 7.670$ & $16.40 \pm 3.400$ & $19.13 \pm 13.47$ & 0121 & 0106 \\
\hline & Day 60 & $13.17 \pm 1.300$ & $14.45 \pm 0.911$ & $14.54 \pm 0.682$ & $13.47 \pm 1.100$ & 0.1261 & 0.100 \\
\hline P-value & 0.267 & & & & & & \\
\hline
\end{tabular}

Explanations: TP - total protein; IgG - immunoglobulin G; BUN - blood urea nitrogen; TG - triglyceride; BHBA - beta-hydroxy butyric acid; ALP - alkalen fosfataz; AST - aspartate aminotransferase; ALT - alanine aminotransferase; T - time; G - group; S - sex 
experimental groups $(\mathrm{P}>0.050)$ (26). In another study, Zdunczyk et al. (45) also determined that a $30 \mathrm{mg} / \mathrm{kg}$ dose of $M$. cordata extract did not improve the final FCR for broilers. On the other hand, some researchers have claimed to have observed a decrease in dry matter intake as a result of high inclusion levels $(>1500 \mathrm{mg} /$ $\mathrm{kg}$ ) of plant extracts (44).

Biochemical analyses of blood are useful to have an idea in the metabolic status of animals. The blood biochemical parameters among the experimental groups are shown in Table 3 . The values of the biochemical variables in calves' serum differ from the mean values in the serum of mature cows (18). Biochemical blood analyses of young ruminants are important indicators of the general health of calves and also ruminal development. The concentrations of serum total protein, BUN, TG and BHBA were in the normal range in this study, which indicates that the animals were healthy and that the M. cordata extract had no negative effect on the calves' growth. In this experiment, no significant differences were observed between the experimental groups $(\mathrm{P}>0.050)$. However, levels of albumin $(\mathrm{P}<0.010)$, BUN $(\mathrm{P}<0.001)$ and BHBA $(\mathrm{P}<0.001)$ varied according to the calves' age. These values change with the age. The physiological condition of the animal, nutrition, and inflammation may influence the TP concentration (16). Serum albumin is a very considerable early nutritional indicator of the protein status of cattle (1). In the current study, TP and IgG levels did not change according to sampled time whereas serum albumin concentrations increased with calves' age $(\mathrm{P}<0.010)$. The increased albumin levels of calves according to their age in our study also agrees with the findings of other researchers (12). At the end of the study, BUN levels decreased in each group $(\mathrm{P}<0.001)$, it was demonstrated that the age of the calves markedly influenced serum BUN level. In other words, as calf starter intake increased in each treatment group, the concentration of BUN decreased. This result agrees with the results of other researchers $(11,22,38)$. Steinhardt and Thielscher (36) also demonstrated that urea concentrations decrease slightly between birth and 2 months of age, when they measure BUN level $27 \mathrm{mg} / \mathrm{dL}$. Based on past research on dairy calves, it is clear that the value of BUN levels was affected by both age and dietary protein levels (22). Khan et al. (17) also claimed that higher crude protein consumption may induce higher levels of BUN.

Tab. 4. Effects of Macleaya cordata extract supplementation to milk on recto-anal bacterial counts of pre-weaning calves

\begin{tabular}{|l|c|c|c|c|c|c|c|}
\hline \multirow{2}{*}{ Parameters } & \multicolumn{2}{c|}{ Groups } & \multicolumn{2}{c|}{ Sex } & \multicolumn{3}{c|}{ P-values } \\
& Control & M. cordata & + & O & G & S & G $\times$ S \\
\hline Lactic acid bacteria & $\mathbf{5 4 \times 1 0 ^ { 3 }}$ & $\mathbf{8 7 \times 1 0 ^ { 4 }}$ & $61 \times 10^{3}$ & $\mathbf{6 4 \times 1 0 ^ { 4 }}$ & $\mathbf{0 . 3 7 6}$ & $\mathbf{0 . 5 4 2}$ & $\mathbf{0 . 1 8 5}$ \\
\hline Total coliforms & $\mathbf{2 4 \times 1 0 ^ { 8 }}$ & $\mathbf{4 5 \times 1 0 ^ { 7 }}$ & $\mathbf{1 8 \times 1 0 ^ { 8 }}$ & $12 \times 10^{9}$ & $\mathbf{0 . 2 9 6}$ & $\mathbf{0 . 1 5 3}$ & $\mathbf{0 . 6 5 8}$ \\
\hline Total aerobic & $\mathbf{8 7 \times 1 0 ^ { 8 }}$ & $\mathbf{9 4 \times 1 0 ^ { 8 }}$ & $12 \times 10^{9}$ & $\mathbf{7 9 \times 1 0 ^ { 8 }}$ & $\mathbf{0 . 8 9 5}$ & $\mathbf{0 . 1 3 0}$ & $\mathbf{0 . 7 5 1}$ \\
\hline
\end{tabular}

Explanations: $\mathrm{G}$ - group; $\mathrm{S}-$ sex
In the current study, BHBA concentrations gradually increased $(\mathrm{P}<0.001)$ with age, while TG concentrations remained unchanged $(\mathrm{P}<0.050)$. In the experiment conducted by Hugi and Blum (11), the researchers found BHBA increments in pre-weaning calves. BHBA is one indicator of rumen development in young calves (33). In the current study, it is considered that the serum BHBA and BUN concentrations changed with calves' age as a result of increasing dry matter intake.

The AST, ALP and ALT show high activity and are important catabolic enzymes, which play a crucial role in liver function of animals. As seen in Table 3, the AST and ALP levels in this study were within the reference intervals indicated in studies by Jezek (14) and Otomaru et al. (30) (Tab. 3). Moreover, there was a statistically significant group $\times$ sex interaction effect on AST in this study $(\mathrm{P}<0.050)$. M. cordata extract supplementation decreased serum AST level in female calves. However, it remains not possible to confirm whether this interaction was due to the effects of the $M$. cordata extract supplementation or to other factors. Kaneko (16) claimed that some serum parameters may vary depending on factors such as sex, age, weather, stress, season and physical exercise. Similarly, some reports have shown that AST activity increases from the $2^{\text {nd }}$ to the $12^{\text {th }}$ week of age (27). Vrankovic et al. (41) demonstrated that the level of serum total ALP in suckling calves is a vulnerable indicator of bone growth. With respect to serum ALP and ALT levels, the control and experimental groups in this study kept reference values, with no differences between them. More research is needed to further assess the role of M. cordata extract in modulating blood parameters, especially hepatic enzymatic activities, in calves of different ages in vivo and its effect on the metabolism and immunity of calves.

Bacteria in the gut are very important factors that contribute to an animals' health and welfare. M. cordata extract supplementation of the calves' milk had no significant effect on the total aerobic, total coliforms, and lactobacillus bacterial counts of the rectoanal swabs. A summary of these results is shown in Table 4. There are no previous reports on the effects of $M$. cordata extracts on recto-anal bacterial counts in calves during the pre-weaning period, but in broilers, Sangrovit reduced pathogenic bacteria in the digestive tract (45). Vienna et al. (40) reported that the antimicrobial properties of plant extracts could be dose-dependent.

In conclusion, Macleaya cordata extract did not improve the growth performance and serum IgG levels of pre-weaning calves, but it did change their metabolic status. These results confirmed that the efficacy of plant 
extracts is dose dependent and must be studied extensively before such extracts can be recommended as efficient feed additives for calves in different conditions. Furthermore, the results of such studies should be confirmed by further studies using different experimental procedures, a greater number of animals, and different doses of Macleaya cordata extract supplements.

\section{References}

1. Agenas S., Heath M. F., Nixon R. M., Wilkinson J. M., Phillips C. J. C.: Indicators of under nutrition in cattle. Anim. Welf. 2006, 15, 149-160.

2. Anderson K., Nagaraja J.: Ruminal metabolic development in calves weaned conventionally or early. J. Dairy Sci. 1987, 70, 1000-1005.

3. $A O A C$ : Official methods of analysis ( $15^{\text {th }}$ ed.). Association of Official Analytical Chemists, Inc., Arlington, Virginia, USA 1990.

4. Bazeley K.: Investigation of diarrhoea in the neonatal calf. In Pract. 2003, 25 , 152-159.

5. Brickell J. S., McGowan M. M., Pfeiffe D. U., Wathes D. C.: Mortality in HolsteinFriesian calves and replacement heifers, in relation to body weight and IGF-I concentration, on 19 farms in England. Animal 2009, 3, 1175-1182.

6. Chaturvedi M. M., Kumar A., Darnay B. G., Chain G. B. N., Agarwal S. Aggarwal B. B.: Sanguinarine (pseudochelerythrine) is a potent inhibitor of NP-kappa B activation, I kappa B alpha phosphorylation, and degradation. J. Biol. Chem. 1997, 272, 30129-30134.

7. Duke J. A.: Handbook of phytochemical constituents of GRAS herbs and other economic plants. CRC Press, Boca Raton, FL 1992.

8. Fraser A. S., Broom D. M.: Farm Animal Behaviour and Welfare. $3^{\text {rd }}$ ed., CAB Publishing UK 1997.

9. Gill C.: Botanical feed additives. Feed Int. 2000, 21, 14-17.

10. Gulliksen S., Lie K., Loken T., Osteras O.: Calf mortality in Norwegian dairy herds. J. Dairy Sci. 2009, 92, 2782-2795.

11. Hugi D., Blum J. W.: Changes of blood metabolites and hormones in breeding calves associated with weaning. Zentralbl. Veterinarmed. A 1997, 44, 99-108.

12. Hugi D., Gut S. H., Blum J. W.: Blood metabolites and hormones - especially glucose and insulin - in veal calves: Effects of age and nutrition. J. Vet. Med. 1997, 44, 407-416

13. Hur T. Y., Jung Y. H., Choe C. Y., Cho Y. I., Kang S. J., Lee H. J., Ki K. S., Baek K. S., Suh G. H.: The dairy calf mortality: The causes of calf death during ten years at a large dairy farm in Korea. Korean J. Vet. Res. 2013, 53, 103-108.

14. Ježek J.: The dynamics of serum immunoglobulin concentrations and hematological and biochemical parameters in the period to the age of 24 weeks in differently reared calves. Univerza v Ljubljani. Veterinarska fakulteta. Ljubljana, Slovenija 2007, p. 172.

15. Kamel C.: Plant extracts in an integrated approach. Feed Mix 2001, 9, 1-14.

16. Kaneko J. J.: Serum proteins and the dysproteinemias, [in:] Kaneko J. J., Harvey J. W., Bruss M. L. (ed.): Clinical biochemistry of domestic animals. Academic Press, ISBN 0-12-396305-2, San Diego, California 1997, p. 117-138

17. Khan M. A., Lee H. J., Lee W. S., Kim H. S., Kim S. B., Ki K. S., Ha J. K., Lee $H$. G., Choi Y. J.: Pre- and postweaning performance of holstein female calves fed milk through step-down and conventional methods. J. Dairy Sci. 2007, 90, 876-885

18. Klinkon M., Ježek J.: Values of blood variables in calves, [in:] Perez-Marin C. C. (ed.): A bird's-eye view of veterinary medicine. Intech Open 2012, p. 301-320.

19. Kosina P., Gregorova J., Gruz J., Vacek J., Kolar M., Vogel M., Roos W. Naumann K., Simanek V., Ulrichova J.: Phytochemical and antimicrobial characterization of Macleaya cordata herb. Fitoterapia 2010, 81, 1006-1012.

20. Kozlowski K., Lecewicz A., Jeroch H., Zdunczyk Z., Jankowski J.: Effect of a phytogenic feed additive from Macleaya cordata on performance and carcass parameters of broilers. Arch. Geflugelkd. 2008, 72, 140-142.

21. Lei Q., Liu H., Yong P., Xiao P.: In silico target fishing and pharmacological profiling for the isoquinoline alkaloids of Macleaya cordata (Bo Luo Hui). Chin. Med. 2014, 10, 1-20.

22. Li H., Diao Q. Y., Zhang N. F., Fan Z. Y.: Growth, nutrient utilization and amino acid digestibility of dairy calves fed milk replacers containing different amounts of protein in the pre-ruminant period. Asian Austral. J. Anim. Sci. 2008, 21, 1151-1158.

23. Lin L., Liu Y. C., Huang J. L., Liu X. B., Qing Z. X., Zeng J. G., Liu Z. Y.: Medicinal plants of the genus Macleaya (Macleaya cordata, Macleaya microcarpa): a review of their phytochemistry, pharmacology, and toxicology. Phytother. Res. 2018, $32,19-48$

24. Lindermayer $H$.: Überprüfung der leistungsfördernden Wirksamkeit des phytogenen Zusatzstoffes Sangrovit bei Mastschweinen. Bayerische Landesanstalt für Landwirtschaft. Institut für Tierernährung und Futterwirtschaft 2005.
25. Liu G., Guan G., Fang J., Martínez Y., Chen S., Bin P., Yin Y.: Macleaya cordata extract decreased diarrhea score and enhanced intestinal barrier function in growing piglets. Biomed. Res. Int. 2016, 1-7.

26. Matulka R., Von Alvensleben S., Morlacchini M., Fusconi G.: Tolerance study for standardized Macleaya cordata extract added to chicken layer diet. Open J. Anim. Sci. 2018, 8, 104-117.

27. Mohri M., Sharifi K., Eidi S.: Hematology and serum biochemistry of Holstein dairy calves: Age related changes and comparison with blood composition in adults. Research Vet. Sci. 2007, 83, 30-39.

28. Moser M., Messikomer R., Pfirter H. P., Wenk C.: Influence of the phytogenic feed additive Sangrovit ${ }^{\mathbb{B}}$ on zootechnical effects in broiler field trials. $14^{\text {th }}$ Europ. Symp. Nutr. 2003, p. 205-206.

29. Ortiz-Pelaez A., Pritchar D. G., Pfeiffer D. U., Jones E., Honeyman P., Mawdsley $J$. J.: Calf mortality as a welfare indicator on British cattle farms. The Vet. J. 2008, 176, 177-181.

30. Otomaru K., Wataya K., Uto T., Kasai K.: Blood biochemical values in Japanese Black calves in Kagoshima Prefecture. The Japan J. Vet. Sci. 2016, 78, 301-303.

31. Postema H. J., Franken P., Van der Ven J. B.: A study in veal calves for a possible correlation between serum immunoglobulin levels, nutrition levels and risk of disease in the first few weeks of the fattening period. Tijdschr. Diergeneesk. 1987, 112, 665-671.

32. Psotova J., Vecera R., Zdarilova A., Anzenbacherova E., Kosina P., Svobodova A., Hrbac J., Jirovsky D., Stiborova M., Lichnovsky V.: Safety assessment of sanguiritrin, alkaloid fraction of Macleaya cordata, in rats. Vet. Med. 2006, 51, $145-155$

33. Quigley J. D., $3^{\text {rd }}$ Bernard J. K.: Effects of nutrient source and time of feeding on changes in blood metabolites in young calves. J. Anim. Sci. 1992, 70, 1543 $-1549$.

34. Saltijeral Oaxac J. A., Galicia L., Guerra J. E., Rogge H. I.: Influence of a feed additive on support of calves during initial growth phase. Dairy Sci. 2015, 98, 625 .

35. Skrabka-Blotnicka T., Rosiński A., Przysieczna E., Woloszyn J., ElminowskaWenda $G$.: The effect of dietary formulation supplemented with herbal mixture on goose breast muscle quality. Report 1: The Effect on the Chemical Composition. Arch. Geflügelkd. 1997, 61, 135-138

36. Steinhardt M., Thielscher H. H.: Reaktionen von milchrindkälbern auf flüssignahrungaufnahme an verschiedenen alterspunkenten vor und während der aufzucht. Tierärztliche Umschau 2000, 55, 663-673.

37. Tanaka T., Metori K., Mineo S., Hirotani M., Furuya T., Kobayashi S.: Inhibitory effects of berberine-type alkaloids on elastase. Plant Med. 1993, 59, 200-202.

38. Tao H., Guo F., Tu Y., Si B. W. Xing Y. C., Huang D. J., Diao O. Y.: Effect of weaning age on growth performance, feed efficiency, nutrient digestibility and blood-biochemical parameters in Droughtmaster crossbred beef calves. AsianAustralasian J. Anim. Sci. 2018, 31, 864-872.

39. USDA: Dairy 2007 Part II: Changes in the U.S. Dairy Cattle industry, 1991-2007. Fort Collins: USDA-APHIS-VS, CEAH. 2007, p. 57-61

40. Vienna C., Graz R. B., Hohenheim R. C., Milano D. T., Trieste A. T., Wien K. Study on the assessment of plants/herbs, plant/herb extracts and their naturally or synthetically produced components as "additives" for use in animal production. CFT/EFSA/FEEDAP/2005/01. EFSA Supporting Publications 4, 2007, p. $140-154$

41. Vranković L., Aladrović J., Ljubić B. B., Pipal I., Prvanović-Babić N., Mašeke T. Stojević Z.: Blood biochemical parameters of bone metabolism in cows and calves kept in a beef suckler system during the early postpartum period. Livest. Sci. 2018, 211, 8-13

42. Walker W. L., Epperson W. B., Wittum T. E., Lord L. K., Rajala-Schultz P. J., Lakritz J.: Characteristics of dairy calf ranches: morbidity, mortality, antibiotic use practices, and biosecurity and biocontainment practices. J. Dairy Sci. 2012, 95, 2204-2214

43. Williams P., Losa R.: The use of essential oils and their compounds in poultry nutrition. World Poult. 2001, 17, 14-15.

44. Yan L., Meng Q. W., Kim I. H.: The effect of an herb extract mixture on growth performance, nutrient digestibility, blood characteristics and fecal noxious gas content in growing pigs. Livest. Sci. 2011, 141,143-147.

45. Zdunczyk Z., Gruzauskas R., Juskiewicz J., Semaskaite A., Jankowski J., Godycka I., Klos J., Jarule V., Miezeliene A., Alencikiene G.: Growth performance, gastrointestinal tract responses, and meat characteristics of broile chickens fed a diet containing the natural alkaloid sanguinarine from Macleaya cordata. The J. Appl. Poult. Res. 2010, 19, 393-400.

46. Zhao L., Alvensleben S., Fusconi G., Morlacchini M.: Safety evaluation of a standardized Macleaya cordata extract in a ninety day feeding study in weaned piglets. Open J. Anim. Sci. 2017, 7, 213-231

Corresponding author: Nese Nuray Toprak, PhD, Department of Animal Science, Faculty of Agriculture, University of Ankara, 06110, Ankara, Turkey; e-mail: nndede@agri.ankara.edu.tr 